\title{
ABORTION ACCORDING TO HERBAL CONSUME AND PARITY IN THE PRIVATE PRACTICE MIDWIFE CLINIC OF HAJJAH GUNARTI BANJAR BARU
}

\author{
Siska Dhewi ${ }^{1}$, Ahmad Zacky Anwary ${ }^{2}$ \\ Public Health Faculty of UNISKA MAB, Adhayaksa Street, Kayu Tangi No.2, Sub-district of Sungai Miai, \\ District of North Banjarmasin, Banjarmasin City, South Kalimantan 70123, Indonesia
}

\begin{abstract}
Abortion is a world problem that greatly affects the health, illness and death of pregnant women. The data of the Hj. Gunarti Clinic there were 27 cases of mothers who experienced abortion in 2018, while in 2019, there were an increase of 38 cases. The purpose of this study was to determine the correlation between maternal habits in consuming herbs during pregnancy and maternal parity with the spontaneous abortion prevalence. The research design used is case control, with a ratio of 1:1. There were 38 samples as a cases group and 38 control group samples. The study was conducted at the Private Practice Midwife Clinic of Hj. Gunarti Banjarbaru city, South Kalimantan Province in April to June 2020. The results of the study showed a significant correlation between the habit of consuming herbal medicine with the abortion cases, that mothers with the habit of consuming herbal during pregnancy had a 3.58 times greater risk of having abortion compared to women who did not consume herbal during pregnancy (OR $=3.58,95 \%$ CI: 1.267-10.143, $p$ value $=0.026)$, and there is a significant correlation between parity and the abortion cases, mothers with high-risk parity (parity> 3) have a risk of 2.95 times greater abortion than mothers with low-risk parity levels $(O R=2.95,95 \%$ CI: $1.159-7.503, p$ value $=0.039)$. It is recommended for health workers to be more active in socializing to the pregnant women not to consume any herbal medicine carelessly, especially those who do not have permit from the drug and food regulatory agencies, so as to avoid the occurrence of unwanted abortion. In addition to that it also further improves the achievements of the family planning program to be able to limit the number of maternal pregnancies in the community.
\end{abstract}

Keywords: Abortion, Herbs Consumption, Parity

\begin{abstract}
ABSTRAK
Abortus merupakan masalah dunia yang sangat mempengaruhi kesehatan, kesakitan dan kematian ibu hamil. Data klinik Bidan Praktek Swasta Hj.Gunarti terdapat 27 kasus ibu yang mengalami abortus tahun 2018, sedangkan tahun 2019, mengalami kenaikan sebanyak 38 kasus. Tujuan penelitian ini adalah mengetahui hubungan variabel kebiasaan ibu dalam mengonsumsi jamu selama hamil dan paritas ibu dengan kejadian abortus spontan. Desain penelitian yang digunakan adalah case control, dengan perbandingan $1: 1$. Terdapat 38 sampel sebagai kelompok kasus dan 38 sampel kelompok kontrol. Penelitian dilakukan di Klinik Bidan Praktek Swasta Hj. Gunarti kota Banjarbaru Provinsi Kalimantan Selatan pada bulan April hingga Juni tahun 2020. Hasil penelitian terdapat hubungan yang bermakna antara kebiasaan mengkonsumsi jamu dengan kejadian abortus, bahwa ibu dengan kebiasaan mengkonsumsi jamu saat hamil berisiko 3,58 kali lebih besar mengalami abortus dibandingkan ibu yang tidak mengkonsumsi jamu saat hamil ( $\mathrm{OR}=3,58,95 \% \mathrm{CI}: 1,267$ $10,143, p$ value $=0,026$ ), dan terdapat hubungan yang bermakna antara paritas dengan kejadian abortus, ibu dengan paritas yang berisiko tinggi (paritas $>3$ ) memiliki risiko 2,95 kali lebih besar mengalami abortus dibandingkan ibu yang tingkat paritasnya berisiko rendah $(\mathrm{OR}=2,95,95 \% \mathrm{CI}: 1,159-7,503, p$-value $=0,039)$. Disarankan bagi petugas kesehatan untuk lebih aktif dalam mensosialisasikan kepada ibu hamil untuk tidak mengkonsumsi obat herbal secara sembarangan, terutama yang tidak memiliki izin dari badan pengawas obat dan makanan, sehingga dapat menghindari terjadinya abortus yang tidak diinginkan. Selain itu juga agar semakin meningkatkan pencapaian program keluarga berencana untuk dapat membatasi jumlah kehamilan ibu di masyarakat.
\end{abstract}

Kata Kunci: Abortus, Konsumsi Jamu, Paritas

\footnotetext{
${ }^{1}$ Correspondence Address: Siska Dhewi, Adhayaksa Street, Kayu Tangi No.2, Sub-district of Sungai Miai, District of North Banjarmasin, Banjarmasin City, South Kalimantan 70123, Indonesia, E-mail : siskadhewi1987@gmail.com
} 


\section{Introduction}

Abortion is a world problem that significantly affects the health, illness and death of pregnant women. Abortion is the expenditure of conception that occurs at gestational age $<20$ weeks and fetal body weight $\leq 500$ grams. The impact of abortion if it does not get direct treatment quickly and precisely, it will increase the maternal mortality rate, that caused by complications from abortion complications from abortion such as bleeding, perforation, infection and shock. ${ }^{1}$ Abortion or miscarriage in pregnant women is not only a health risk, but can also cause the death. If there is an abortion prevalence, the patient must be treated immediately to get treatment and stop the bleeding, which can endanger the lives.

The frequency of spontaneous abortion in Indonesia is $10 \%-15 \%$ of the 5 million pregnancies annually or 500,000-750,000. While artificial abortion is around 750,000-1.5 million annually. This frequency can reach $50 \%$ when calculated for those who are very early, menstruating late for a few days so that the woman herself does not know that she is pregnant. The death rate due to abortion reaches 2500 every year. ${ }^{2}$ Mothers who have high parity or multipara are at risk of abortion. The number of cases in the study results describe that abortion often occurs at more than four times of parity (grande multipara). The abortion cases in mothers at high parity is related to maternal health due to lack of rest and pregnancy that is too close, especially when accompanied by abortion in previous pregnancies. ${ }^{3}$ Abortion is often associated with cases of bleeding and death in pregnant women. The abortion cases in Indonesia reaches 2.3 million annually. Age and parity are the main factors causing abortion in Indonesia. ${ }^{4}$ Abortion in pregnant women is mostly caused by parity, history of maternal disease, physical activity, maternal age, and herbal consumption. More than $80 \%$ of abortions occur at 12 weeks of gestation, and at least half are caused by chromosomal abnormalities. Repetitive pregnancy causes damage to the blood vessels of the uterine wall, which affects the circulation of nutrients to the fetus will be reduced compared to previous pregnancies, and this condition can cause death in infants. ${ }^{5}$ All individuals who can become pregnant, including women, girls and those with varying gender identities, and who seek medical abortion care should be provided with all of the necessary information to make an informed decision to ensure the promotion of their health and human rights, including sex and gender equality and non-discrimination. ${ }^{6}$

Jamu is a traditional herbal medicine as one of the efforts that have been widely recognized and utilized by the community with the purpose of treating minor ailments, preventing illness, maintaining resilience and health. Drinking lot of herbs found in the Java community both in pregnant women, childbirth, and post-partum (puerperal). ${ }^{7}$ Although herbal medicine has a beneficial value, on the one hand it can also endanger health if it is not wise to consume it. 
Ignorance can cause traditional medicine to turn into harmful ingredients. ${ }^{8}$ The maternal mortality rate (MMR), according to the South Kalimantan Provincial Health Office in 2016 was 92 cases of maternal deaths. In 2017 the highest number of maternal deaths was in Banjar District, which was 7 mothers. Based on data obtained from the Hajjah Gunarti clinic, that the number of pregnant women who experienced abortion in 2017 there were 27 mothers, and there was an increase to 38 in 2018. In the Banjarbaru area, South Kalimantan, there is even one location where the residents produce traditional herbal medicine, with a location in the Loktabat area so that it is referred to as the "Kampung Pejabat" which stands for the Village of Making the Loktabat Herbal Medicine.

The purpose of this study is to know the correlation between the consumption of herbal medicine and maternal parity with the spontaneous abortion cases at the $\mathrm{Hj}$. Gunarti's Clinic in Banjarbaru. This research is important because it can prove the risk factors of the dangers of consuming herbs by the mother during pregnancy, especially herbs that are not registecasecontrolred with the Drug and Food Regulatory Agencies, as well as the risk of high parity with the abortion cases in pregnant women. Research related to the consumption of herbal medicine with the occurrence of abortion is still very rarely done, so researchers interested in these variables. The purpose of this study was to determine the correlation between maternal habits in consuming herbs during pregnancy and maternal parity with the spontaneous abortion prevalence

\section{Method}

This type of research is an observational study with a case-control design that will measure the comparison of risk factors for the occurrence of spontaneous abortion in respondents in the control group and case group. The sampling technique uses total sampling in the case group obtained based on medical records of abortion cases at the private practice midwife clinic of $\mathrm{Hj}$. Gunarti in the range of January 2019 to March 2020, and by using a ratio of 1:1, the number of samples is 76 mothers, consisting of 38 samples as cases and 38 samples as controls with a purposive sampling technique. The case sample was taken based on medical records in the clinic, while the control sample determined respondents who met the criteria based on the similarity of characteristics and location of residence adjacent to the case group. The inclusion criteria determined in the case group were mothers who had come to the examination and had experienced an abortion at the $\mathrm{Hj}$. Gunarti clinic. As for the exclusion criteria are mothers who refuse to be respondents. The inclusion criteria for the sample in the group are mothers who have had a pregnancy check-up at $\mathrm{Hj}$. Gunarti clinic. As for the exclusion criteria are mothers who refuse to be respondents. The study was conducted at the $\mathrm{Hj}$. Gunarti clinic in Banjarbaru city, South Kalimantan Province from April to June 2020. How to determine the results of measuring the variable abortion cases and herbal consumption habits in pregnant women, namely by giving two 
categories consisting of cases or no cases. while the parity variable is categorized into 2 levels, namely a high risk if parity is more than three times, and low risk is determined if parity is less than three times.

The variables in this study are the abortion cases as the dependent variable, as well as the consumption of herbal medicine (unregistered) and parity as the independent variable. The questionnaire instrument was used to collect primary data specifically related to the variables studied, in contrast for medical records, it was used as secondary data specifically related to data about abortion cases. The research data were analyzed using the Chi-square test by measuring the Odds Ratio value to determine the level of risk of each studied variable. This research has received ethical approval number; 177/UNISKA-LP2M/V/2020 issued by the Institute for Research and Community Service of UNISKA MAB.

\section{Results}

Table 1. Characteristics of Respondents and Research Variable

\begin{tabular}{|c|c|c|c|c|}
\hline Characteristics and Variables & f (Case) & $\%$ & f (Control) & $\%$ \\
\hline \multicolumn{5}{|l|}{ Age } \\
\hline Adolescent $(17-25$ years $)$ & 17 & 44.7 & 15 & 39.5 \\
\hline Adult ( $26-45$ years $)$ & 21 & 55.3 & 23 & 60.5 \\
\hline \multicolumn{5}{|l|}{ Education Level } \\
\hline Basic (Elementary School) & 9 & 23.7 & 3 & 7.9 \\
\hline Intermediate (Secondary-High School) & 26 & 68,4 & 27 & 71 \\
\hline High (High Education) & 3 & 7.9 & 8 & 21.1 \\
\hline \multicolumn{5}{|l|}{ Herbs Consumption } \\
\hline Yes & 17 & 44.7 & 7 & 18.4 \\
\hline No & 21 & 55.3 & 31 & 81.6 \\
\hline \multicolumn{5}{|l|}{ Parity } \\
\hline High Risk & 23 & 60.5 & 13 & 34.2 \\
\hline Low Risk & 15 & 39.5 & 25 & 65.7 \\
\hline
\end{tabular}

From table 1, it can be seen that the age of most respondents in the cases group is in the range of 26 - 45 years, which are 21 mothers (55.3\%). While the level of education itself is more in the middle category, with 27 mothers (71\%) having secondary education on the control group. From the table 1 obtained that there were 17 mothers (44.7\%) from cases group who consumed herbs during pregnancy. Then there were also 23 mothers $(60.5 \%)$ of cases group that included in high-risk parity.

Table 2. Correlation of Herbal Consumption and Parity with The Abortion Cases

\begin{tabular}{|c|c|c|c|c|c|c|c|c|}
\hline & \multicolumn{4}{|c|}{ Abortion cases } & \multirow{3}{*}{ n } & \multirow{3}{*}{$\%$} & \multirow{3}{*}{ p value } & \multirow{3}{*}{$\begin{array}{c}O R \\
(95 \% \mathrm{CI})\end{array}$} \\
\hline & \multicolumn{2}{|c|}{ Case } & \multicolumn{2}{|c|}{ Control } & & & & \\
\hline & $\mathbf{n}$ & $\%$ & n & $\%$ & & & & \\
\hline \multicolumn{9}{|c|}{ Herbs Consumption } \\
\hline Yes & 17 & 44.7 & 7 & 18.4 & 24 & 31.6 & \multirow{2}{*}{0.026} & 3.58 \\
\hline No & 21 & 55.3 & 31 & 81.6 & 52 & 684 & & $(1.267-10.143)$ \\
\hline \multicolumn{9}{|l|}{ Parity } \\
\hline High Risk & 23 & 60.5 & 13 & 34.2 & 36 & 47.4 & \multirow{3}{*}{0.039} & \multirow{3}{*}{$\begin{array}{c}2.95 \\
(1.159-7.503)\end{array}$} \\
\hline Low Risk & 15 & 39.5 & 25 & 65.8 & 40 & 52.6 & & \\
\hline Total & 38 & 100 & 38 & 100 & 76 & 100 & & \\
\hline
\end{tabular}


Based on table 2 shows that the proportion of abortion in pregnant women in the case group is $44.7 \%$; the risk factor is the consumption habits of unsafe herbs during pregnancy. Based on the analysis of Odds Ratio, it is known that mothers who consume herbal medicine have a risk of 3.58 times having abortion compared to women who do not consume herbal medicine (OR $=3.76$; 95\% CI: 1.267-10.143). Chi-square analysis results showed a probability value of $0.026(\mathrm{p}<0.05)$, which means there is a significant relationship between the habits of herbs consumption with the abortion cases.

Based on table 2, can be seen that the abortion cases in the group of cases there are as many as $60.5 \%$ where the cause is the level of parity that is at risk of giving birth more than three times. In the parity variable, mothers who are in the high risk category (parity $>3$ ) have a 2.93 times greater risk of experiencing an abortion prevalence than mothers with a parity number $\leq 3$ times $(\mathrm{OR}=2.95 ; 95 \% \mathrm{CI}: 1.159-7.503)$. In addition, the results of statistical analysis using the ChiSquare test showed the value of $p=0.011(p<0.05)$ so that it can be interpreted that there is a correlation between the number of maternal parity with the abortion cases.

\section{Discussion}

Based on data on the characteristics of respondents regarding maternal age, the majority are in the adult age range of $26-45$ years. In the case group, there were $55.3 \%$ of respondents in the adult category experienced an abortion. While in the control group, most respondents were also in the adult age range of $60.5 \%$. The results of the research data related to the age of this respondent, similar to a study conducted at Al-Islam Hospital Bandung which illustrates that the age of the respondents there are $48.6 \%$ aged between 20 to 34 years, and there are $45.8 \%$ of the sample aged over 35 years old. ${ }^{9}$ This it can be concluded that most mothers who experience abortion are those who are adults and lead to old age.

The results of this study indicate that the average abortion cases occur due to miscarriage (spontaneous abortion), where most do not make adequate health efforts such as adequate rest or consuming nutritious food according to the nutritional needs of pregnant women. In a similar study, it was found that the majority of pregnant women in the high risk category experienced abortion as many as 42 respondents $(66.7 \%) .{ }^{10}$ Whereas in other studies mentioned that there were 48 people included in the group of cases that experienced spontaneous abortion cases based on several risk causes. ${ }^{11}$

Quite a lot of people, especially pregnant women who have a habit of consuming herbs, are a common culture in Indonesia and South Kalimantan in particular. Herbal medicine is a traditional herb as one of the well-known treatment efforts and is used by the community with the aim of treating minor illnesses, preventing the arrival of diseases, maintaining endurance and health of the body. The habit of drinking herbal medicine is found in many people in Java, both pregnant 
women, childbirth and postpartum (postpartum). ${ }^{7}$ Traditional medicines (both in the form of herbs and medicinal plants) are still widely used by the community, especially from the lower middle class. Even from time to time, traditional medicine is experiencing increasing development increasingly, especially with the emergence of the issue of returning to nature (back to nature) and a prolonged crisis. However, in its development, often found inaccuracies in the use of traditional medicines because of misinformation and mistaken assumptions of traditional medicines and how to use them. ${ }^{8}$ In the similar study mentioned that there was a relationship between herbal consumption during pregnancy with the incidence of Asphyxia in newborns. From the results of the study mentioned that $37.5 \%$ of respondents consumed herbal medicine in early age of pregnancy (1-3 months of pregnancy period), $18.8 \%$ of respondents consumed herbal medicine at 4-7 months of pregnancy period, and $6.3 \%$ of respondents consumed herbal medicine at 8-9 months of pregnancy period. ${ }^{12}$ The thing that is often not realized by mothers who routinely consume traditional herbal medicine during the pregnancy process is ignorance of the types of ingredients making these herbs, where there are several types of herbs that are dangerous for pregnancy, such as galingale and ginseng. Public confidence in the consumption of certain traditional herbs is based on habits that have become hereditary in Indonesia. As a result of research in Madura which has explained that various issues related to quality certification, products safety of traditional herbal, and the opinion of medical staff who do not recommend herbal medicine as an alternative medicine, made Madura herbal medicine in an unclear existence that is trusted but on the other hand it is also not recognized. ${ }^{13}$ In other studies about traditional herbs also mentioned that Kalimantan community itself has a traditional herb derived from plants in the mountains of Meratus, namely Alaban bark (Vitex Pubescens Vahl), whose function is used to reduce low back pain and stomach pain by drinking the herbal medicine boiled water, there are several types of traditional herbal medicine, and packaged herbs that use these ingredients as the concoction. Laban bark is not only used by the community as a tea drink. Almost all respondents know the efficacy possessed by the bark of Laban, which is as a stomachache medicine. ${ }^{14}$

But for pregnant women who have complaints of back pain and then consuming traditional herbs is risky because it can inhibit the absorption of iron as many respondents do in the case group in this study. Risk factors that can cause anemia in pregnant women are often consuming foods that contain substances that can inhibit iron absorption, such as phytate and tannins. ${ }^{15}$ Among the studied medicinal herbs, Polygonum, Origanum marjorana, Multiflorum, Echium, Foeniculum vulgare, Vitex agnus castus, Blue cohosh, Montanoa tomentosa and Tripterygium wilfordii had teratogenic and toxic effects on embryo. Ginseng, Dong quai, Anethum graveolens.L induce menstruation by affecting en-menstruation hormones, Castor oil, and Evening primrose oil induce uterine contraction and Mentha pulegium increases the risk of abortion. ${ }^{16}$ The Dayak Ngaju tribe believes that lengkuas (Alpiniagalanga) can abort a new pregnancy. The rhizome which was 
pounded and then squeezed and drunk can be dangerous for mothers who were pregnant. In addition to abortion, a galangalwas also believed to be used as natural contraceptive drugs. ${ }^{17}$ Parity is the number of children born to either alive or dead until the survey is carried out excluding babies being conceived. Parity is grouped into 2 categories: ideal parity ( $\leq 2$ children) and not ideal parity ( $>2$ children). ${ }^{18}$

Pregnancy and childbirth post date with the first child at risk increased mainly because the mother had never experienced a pregnancy childbirth, and at the grandmultipara pregnancy postdate more increased, because too often experience pregnancy and childbirth so it affects the contractions of the mother. ${ }^{19}$ Parity is the number of deliveries a mother has experienced, whether born or dead. Parity 2 to 3 is the safest parity in terms of maternal mortality. Mothers with high parity more than 3 have high maternal rates because endometrial disorders can occur. The cause of endometrial disorders is due to repeated pregnancy. While the first parity is risky because the uterus is the first time to receive the results of conception and uterine muscle flexibility is still limited to fetal growth.

The habit of consuming herbal medicine in pregnant women is a common habit among people in Indonesia, as is the case in South Kalimantan in particular. Though health experts have said that many pregnant women are not advised to consume any type of herbal medicine except those that have been registered and guaranteed safety. Because these habits have become a tradition that is difficult to break, so far there are still many people who are less aware of the negative impacts that may occur due to consuming herbs that are not guaranteed quality and safety. Although there has not been much empirical evidence related to the definite influence between the consumption habits of herbs during pregnancy on the occurrence of abortion, but there are several studies related to this, that state the certain types of herbs can have a risk or harmful effect on the pregnancy of the mother if mistaken in their use. Excessive consumption of herbs due to ignorance, especially herbs that contain ingredients such as ginger and kencur especially those found in many parts of Kalimantan are very risky to make a miscarriage in the womb.

The results of this study are in line with research that states that there is a significant relationship between the consumption of herbal medicine and the incidence of Asphyxia in newborns in Bekasi $(\mathrm{p}=0.000$; odds ratio $(\mathrm{OR})=6.89 ; 95 \% \mathrm{CI}=4.14-11.38)$. The study also explained that pregnant women should avoid drinking herbal puyang chillies containing Java chili (piper retrofractum vahl) continuously because it has the effect of inhibiting muscle contractions in labor. ${ }^{20}$ The other research states that based on the results of the Chi-square test, obtained $p=0.000$ $<0.05$ so that it can be concluded there is a relationship between herbal consumption during pregnancy with the incidence of Asphyxia in newborns. ${ }^{12}$ Pregnant women have a poor knowledge of pregnant herbs at $75 \%$. This is due to the still limited scientific information about pregnant herbs that are obtained in detail by pregnant women and the community. ${ }^{21}$ As a comparison, in other 
studies it was even mentioned that herbs can be specifically used to make an abortion, which means that there are certain types of herbs that are not safe for pregnancy. Natural herbs possess miraculous powers to compete with surgical abortion. Herbal abortion may prove to be a better option as compared to surgical abortion. However, the results we got from our study reveal people's lack of knowledge regarding herbal drugs for abortion, which makes people hesitant to use them. ${ }^{22}$ Beside the therapeutic effects, somer medicinal herbs have side effects on pregnancy development and embryonic growth, so that today, the use of medicinal herbs is considered as an important question in communities. The use of medicinal herbs requires awareness and consumption standards in pregnant women. ${ }^{16}$

The more maternal parity level, the higher the risk of miscarriage due to the possibility of damage to the blood vessels and the mother's uterus. Likewise, if a new mother experiences a first pregnancy, she will also have a high risk of abortion because she has never had childbirth experience so that her reproductive organs are not ready to accept different conditions. Based on the other research that describe there was a significant relationship between parity and the abortion cases $(\mathrm{p}=0.003)$. Mothers with parity $>3$ had a 2.98 times greater risk for abortion than mothers with parity $\leq 3(\mathrm{OR}=2.98 ; 95 \% \mathrm{CI}: 1.502-5.933) .{ }^{23}$ Mothers who have parity $>3$ have a 6.9 times greater risk than mothers who have parity $1-3 .{ }^{24}$ In accordance with the results of research conducted at the regional general hospital of Kota Bumi mention that Chi-square test results reported that the value of $\rho$ value 0.016 , meaning smaller than the alpha value $(\alpha=0.05)$. Thus it can be concluded statistically with a degree of confidence of $95 \%$, there is a relationship between parity and incomplete abortion. ${ }^{25}$

The results of this study are in line with research which shows that there is a significant relationship between parity and the incidence of incomplete abortion and complete abortion in pregnant women at Sultan Agung Islamic Hospital in Semarang in 2014 shown by the Chi-square test $\mathrm{p}=0.021$ where the $\mathrm{p}$ value $<0.05$. In that study parity of pregnant women is a factor that has a risk of abortion as indicated by $(\mathrm{OR}=3.000)$ meaning that respondents with high risk parity have a risk of experiencing incomplete abortion and complete abortion 3 times compared to respondents whose parity is low risk.(12) Another study illustrates that the results of the Odds Ratio analysis show a significant relationship between parity and abortion ( $\mathrm{OR}=10.2$; 95\% CI: 4.755-22.249) which means mothers with high-risk parity have a 10.2 times greater risk of experiencing an abortion than mothers whose parity levels are low risk, with a $\mathrm{p}$ value $=0.001$.(11) Continuity correction test results obtained by $\left(X^{2}\right)=28.022$ with Asymp.sig value $(\rho)=0.000<\alpha=0.05$, means significant, then $\mathrm{H}_{0}$ is rejected and $\mathrm{H}_{a}$ is accepted, meaning that there is a significant relationship between parity and abortion in RSUD Dr. M. Yunus Bengkulu. ${ }^{26}$ Limitation in this study is the difficulty of getting references related to research on the relationship of herbal consumption with the abortion cases. 


\section{Conclusion}

There is a significant relationship between the habit of consuming herbs with the occurrence of abortion. Based on the results of the Odd Ratio analysis, it can be concluded that mothers with the habit of consuming herbs during pregnancy can be at risk 3.58 times more likely to experience abortion than mothers who do not consume herbs during pregnancy. There is also a significant relationship between parity and the abortion cases. Based on the results of the Odds Ratio analysis, it can be concluded that mothers with high-risk parity (parity $>3$ ) have a 2.95 times greater risk of having an abortion than women with low-risk parity.

It is recommended for health workers to be more active in socializing to pregnant women not to consume any herbal medicine carelessly, especially those who do not have permit from the drug and food regulatory agencies during the pregnancy process so as to avoid the occurrence of unwanted abortion. In addition to that, it also further improves the achievements of the family planning program to be able to limit the number of maternal pregnancies in the community.

\section{Acknowledgement}

A word of thanks goes to the Head of the Research Institute and Community Service. also given to the Dean of Public Health Faculty UNISKA MAB, as well as to Hj. Gunarti as the owner of the clinic.

\section{Funding}

The research was carried out independently, so there was no funding for research.

\section{Conflict of Interest}

The researcher stated that there was no conflict of interest in this research.

\section{References}

1. Sujiyatini, Mufdlilah, Hidayat A. Asuhan Patologi Kebidanan, Plus Contoh Asuhan Kebidanan. Pertama. Yogyakarta: Nuha Medika; 2009. 1-180 p.

2. Yanti L. Faktor Determinan Kejadian Abortus pada ibu Hamil: Case Control Study. MEDIASAINS Jurnal Ilmiah Ilmu-ilmu Kesehatan. 2018;16(2):95-100.

3. Handayani EY. Hubungan Umur dan Paritas Dengan Kejadian Abortus Di RSUD Kabupaten Rokan Hulu. Journal of Martenity Neonatal. 2015;1(6):249-53.

4. Akbar A. Faktor Penyebab Abortus Di Indonesia Tahun 2010-2019: Studi Meta Analisis. Jurnal Biomedik. 2019;11(3):182-91.

5. Rochmawati PN et al. Faktor-faktor yang Mempengaruhi Abortus di Rumah Sakit Umum Pusat DR. Soeradji Tirtonegoro Klaten. Skripsi, Universitas Muhammadiyah Surakarta; 
2013.

6. WHO. Medical management of abortion. Geneva: WHO Publication; 2018. 1-72 p.

7. Paryono AK. Kebiasaan Konsumsi Jamu untuk Menjaga Kesehatan Tubuh Pada Saat Hamil dan Setelah Melahirkan di Desa Kajoran Klaten Selatan. Jurnal Terpadu Ilmu Kesehatan. 2014;3(1):64-72.

8. Ningsih IY. Modul Saintifikasi Jamu (Keamanan Jamu Tradisional). In: Modul Saintifikasi Jamu. 2016. p. 1-39.

9. Mustikawati A, Wijayanegara H, Dewi MK. Hubungan antara Karakteristik Ibu dengan Kejadian Abortus Spontan di Bagian Kebidanan Rumah Sakit Al-Islam Bandung Periode 1 Januari 2030 - 31 Desember 2014. In: Prosiding Penelitian Sivitas Akdemika Unisba (Kesehatan). 2015. p. 646-53.

10. Amalia LM, Sayono. Risk Factors Incident Abortion (Studies in Islamic Hospital Sultan Agung Semarang). Jurnal Kesehatan Masyarakat Indonesia. 2015;10(1):23-9.

11. Silitonga JM, Sitorus RJ. Faktor-Faktor Penyebab Kejadian Abortus Spontan Di Rumah Sakit Umum Pusat Dr. Mohammad Hoesin Palembang. Jurnal Ilmu Kesehatan Masyarakat. $2017 ; 8(2): 100-8$.

12. Anggraeni W, Sari KIP, Wardani RA. Hubungan Antara Konsumsi Jamu Saat Hamil Dengan Kejadian Asfiksia Bayi Baru Lahir Di Ruang Melati RSUD Jombang. Nurse and Health; Jurnal Keperawatan. 2017;6(2):60-4.

13. Satriyati E. Menjaga Tradisi Minum Jamu Madura Dengan Penyampaian Pesan Interpersonal Kesehatan Antara Peramu dan Pengguna. Jurnal DIMENSI. 2017;10(2):2435.

14. Adelina K, Wardenaar E, Sisillia L. Kajian Etnobotani dan Fisiko Kulit Kayu Laban (Vitex pubescens Vahl) di Desa Lape Kecamatan Kapuas Kabupaten Sanggau Kalimantan Barat. Jurnal Hutan Lestari. 2014;2(1):92-9.

15. Machmud PB, Hatma RD, Syafiq A. Tea Consumption and Iron-Deficiency Anemia Among Pregnant Woman in Bogor District, Indonesia. Media Gizi Mikro Indonesia. 2019;10(2):91-100.

16. Esmaeilzadeh M, Moradi B. Medicinal Herbs with Side Effects During Pregnancy - An Evidence-Based Review Article. The Iranian Journal of Obstetrics, Gynecology and Infertility. 2017;20(Nov):9-25.

17. Rohmat S, Nisyawati, Rahayu SE. Diversity of medicinal plants for pregnancy and postpartum care of Dayak Ngaju tribe in Mantangai sub-district, Kapuas regency, Central Kalimantan. Journal of Physics: Conference Series. IOP Publishing. 2019;1317(1):1-8.

18. Kurniawan R, Melaniani S. Hubungan Paritas, Penolong Persalinan dan Jarak Kehamilan dengan Angka Kematian Bayi di Jawa Timur. Jurnal Biometrika dan Kependudukan. 
2019;7(2):113.

19. Apriyanti F, Fiska Y. Hubungan Paritas Dengan Kejadian Kehamilan Post Date Di rumah sakit Bangkinang Tahun 2012. Jurnal Kebidanan STIKes Tuanku Tambusai Riau. 2014;5(November):59-68.

20. Purnamawati D, Ariawan I. Konsumsi Jamu Ibu Hamil sebagai Faktor Risiko Asfiksia Bayi Baru Lahir. Jurnal Kesehatan Masyarakat Nasional. 2012;6(6):267-72.

21. Sumarni. Hubungan Antara Pengetahuan Tentang Jamu Hamil Dengan Konsumsi Jamu Pada Ibu Hamil di Kelurahan Karangklesem Kecamatan Purwokerto Selatan Tahun 2019. Bidan Prada; Jurnal Publikasi Kebidanan. 2019;10(1):111-20.

22. Gul S, Rubab B, Ahmad N, Iqbal U. Herbal drugs for abortion may prove as better option in terms of safety, cost \& privacy. Journal of Scientific and Innovative Research. 2015;4(2):105-8.

23. Matjino SH. Faktor Risiko Kejadian Abortus di RSUD Dr. Chasan Boesoirie Ternate Provinsi Maluku Utara. Tesis, Universitas Hasanuddin; 2013.

24. Hamidah SM. Faktor dominan yang berhubungan dengan kejadian abortus imminens. Jurnal Ilmu dan Teknologi Kesehatan. 2013;1(1):29-33.

25. Maliana.AS A. Faktor-faktor yang Berhubungan dengan Kejadian Abortus Inkomplit di Ruang Kebidanan RSUD Mayjend. HM. Ryacudu Kota Bumi. Jurnal Kesehatan. 2016;VII(1):17-25.

26. Silviani YE, Epiani. Faktor-faktor yang Berhubungan Dengan Kejadian Abortus di RSUD dr.M Yunus Bengkulu. Jurnal Informasi Kesehatan Indonesia (JIKI). 2018;4(1):64-78. 